\title{
Preparation of Hop Estrogen-Active Material for Production of Food Supplements
}

\author{
Marcel Karabín, Tereza Haimannová, Kristýna Fialová, Lukáš Jelínek and Pavel Dostálek *(D) \\ Department of Biotechnology, Faculty of Food and Biochemical Technology, University of Chemistry and \\ Technology, Technická 5, 16628 Prague 6, Czech Republic; marcel.karabin@vscht.cz (M.K.); \\ tereza.haimannova@gmail.com (T.H.); fialova.kristyna@centrum.cz (K.F.); lukas.jelinek@vscht.cz (L.J.) \\ * Correspondence: Pavel.Dostalek@vscht.cz; Tel.: +420-605-742-178
}

Citation: Karabín, M.; Haimannová,

T.; Fialová, K.; Jelínek, L.; Dostálek, P. Preparation of Hop Estrogen-Active Material for Production of Food Supplements. Molecules 2021, 26, 6065. https://doi.org/10.3390/

molecules26196065

Academic Editor: Silvie Rimpelová

Received: 16 August 2021

Accepted: 3 October 2021

Published: 7 October 2021

Publisher's Note: MDPI stays neutral with regard to jurisdictional claims in published maps and institutional affiliations.

Copyright: (c) 2021 by the authors. Licensee MDPI, Basel, Switzerland. This article is an open access article distributed under the terms and conditions of the Creative Commons Attribution (CC BY) license (https:// creativecommons.org/licenses/by/ $4.0 /)$.
Abstract: In recent years, the interest in the health-promoting effects of hop prenylflavonoids, especially its estrogenic effects, has grown. Unfortunately, one of the most potent phytoestrogens identified so far, 8-prenylnaringenin, is only a minor component of hops, so its isolation from hop materials for the production of estrogenically active food supplements has proved to be problematic. The aim of this study was to optimize the conditions (e.g., temperature, the length of the process and the amount of the catalyst) to produce 8-prenylnaringenin-rich material by the magnesium oxide-catalyzed thermal isomerization of desmethylxanthohumol. Under these optimized conditions, the yield of 8-prenylnaringenin was $29 \mathrm{mg}$ per $100 \mathrm{gDW}$ of product, corresponding to a $>70 \%$ increase in its content relative to the starting material. This process may be applied in the production of functional foods or food supplements rich in 8-prenylnaringenin, which may then be utilized in therapeutic agents to help alleviate the symptoms of menopausal disorders.

Keywords: hop; prenylflavonoids; desmethylxanthohumol; 8-prenylnaringenin; estrogenic activity; phytoestrogens

\section{Introduction}

Female cones from hops, Humulus lupulus L., contain several important biologically active substances with proven beneficial effects on human health. The use of hops for medicinal purposes dates back many centuries [1,2]. Pharmaceutically important are polyphenolic compounds, especially prenylflavonoids, whose content can be up to $1.7 \%$ wt. in the hop cones depending on the hop variety, harvest year and the agronomic conditions $[3,4]$.

Prenylflavonoids are of particular interest due to their antioxidant [5,6], anti-carcinogenic [7-10], antimicrobial [11,12] and anti-inflammatory properties [13,14]. Moreover, prenylflavonoids are significant for their estrogenic potential [15-17]. Although the estrogenic effects of hops have been known in traditional medicine for a long time [18], the substance responsible for these effects has been identified only relatively recently [16]. The minor hop prenylflavonoid, 8-prenylnaringenin, is considered one of the most potent phytoestrogens currently known, exhibiting approximately 50 times greater estrogenic activity than other well-known phytoestrogens such as genistein or coumestrol [16]. The estrogenic activities of 8-prenylnaringenin are based primarily on its similar chemical structure to endogenous steroidal estrogens, thus resulting in its ability to interact with the estrogen receptors ER $\alpha$ and ER $\beta[16,19]$. Additionally, 8-prenylnaringenin may also act as an enzyme effector. This flavanone stimulates alkaline phosphatase in Ishikawa Var I cells and the growth of the estrogen-dependent MCF-7 breast cancer cell line [20,21]. Moreover, 8-prenylnaringenin inhibits the activity of aromatase [22] that regulates the level of blood estradiol by converting androgens to estrogens [23]. Thus, due to its estrogenic abilities, it could partially attenuate the negative effects of breast cancer treatment with other synthetic aromatase inhibitors [22]. 
Due to the potential of plant substances with estrogenic effects to affect human health through their ability to act as alternatives to human steroidal hormones, attention has recently focused on their use as dietary supplements or in drugs used to alleviate the symptoms of menopausal discomfort [24] caused by insufficient production of estradiol during menopause [25]. These symptoms are usually treated by hormone replacement therapy (HRT), involving the application of relatively high doses of hormones [26]. On the one hand, this treatment eliminates menopausal discomforts (e.g., hot flashes, anxiety and insomnia) and reduces the risk of certain cardiovascular diseases and osteoporosis [27]. On the other hand, it can have negative effects, especially an increased risk of breast and uterine cancer and an increased risk of thrombosis due to blood clotting [17,27].

Studies dealing with 8-prenylnaringenin have primarily focused on its potential use in the prevention of climacteric symptoms, especially to inhibit osteoporosis [15]. It was demonstrated that 8-prenylnaringenin may increase bone mineral density in postmenopausal women and reduce the risk of fractures [28-30]. Due to the positive effects of prenylflavonoids on human health and the potential to use the estrogenically active prenylflavonoids as a complement to HRT, these natural substances could become an important supplement to conventional treatments of menopausal problems.

Food supplements and functional foods enriched in phytoestrogens for ensuring a balanced level of female hormones are already available on the market, but the content of estrogen-active substances is often unspecified and questionable [31,32]. Hops contain variable levels of prenylflavonoids, and the content of 8-prenylnaringenin in hop cones is generally very low (less than $0.01 \% \mathrm{wt}$.) [33], so the estrogenic activities of other prenylflavonoids are almost negligible [34]. Therefore, there is demand for hop material enriched in 8-prenylnaringenin. One option may be through the isomerization of estrogenically inactive desmethylxanthohumol, whose content in hop cones is much higher (0.04-0.22\%wt.) [4] than 8-prenylnaringenin and can naturally produce a mixture of 6prenylnaringenin and 8-prenylnaringenin (Figure 1) [35]. Unfortunately, the ratio of isomerization during the production of beer (which is the only source of hop prenylflavonoids in the human diet) is typically 3:2 in favor of 6-prenylnaringenin [36], whose estrogenic activity is less than $1 \%$ relative to 8-prenylnaringenin [34]. Therefore, a new approach is needed to form 8-prenylnaringenin. The crucial parameters in the preparation of hop material rich in estrogenically active prenylflavonoids are the maximization of desmethylxanthohumol content in the raw material and the determination of the appropriate conditions under which the isomerization equilibrium can be moved in favor of 8-prenylnaringenin.
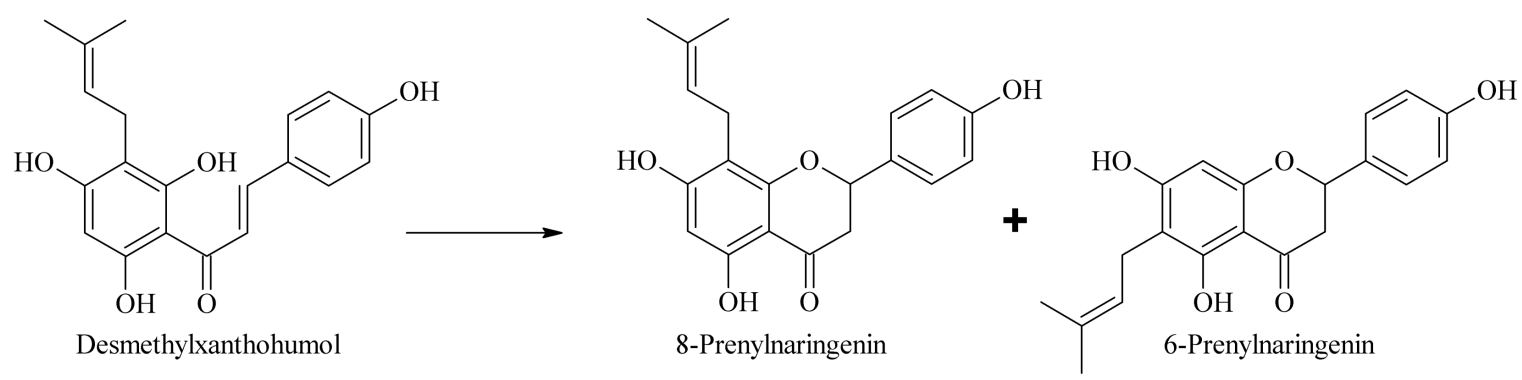

Figure 1. Isomerization of desmethylxanthohumol to 6-prenylnaringenin and 8-prenylnaringenin.

In recent years, the hop-growing industry has focused on breeding new varieties with a higher content of biological active compounds. One of these varieties, Vital, bred and registered in the Czech Republic in 2008, has a high content of prenylflavonoids, especially desmethylxanthohumol (0.3-0.4\%wt. in the hop cones), which is approximately twice that of other varieties [4]. Therefore, his hop variety is suitable as a starting material for pharmaceutical applications and as a starting material for this study [37].

The aim of this study was to determine the appropriate conditions for the isomerization of hop desmethylxanthohumol to achieve a maximum yield of 8-prenylnaringenin. On an industrial scale, this material may then be used in the production of dietary supplements 
that can be used to alleviate the symptoms of menopausal discomfort. Our isomerization procedure was carried out in powder (spent hops after $\mathrm{CO}_{2}$ extraction) rather than a solution and uses food-grade $\mathrm{MgO}$, which allows us to apply lower temperatures. Moreover, there is no isomerization of xanthohumol to isoxanthohumol at these lower temperatures.

\section{Results and Discussion}

To the best of our knowledge, there are only a few techniques for transforming some of the hop prenylflavonoids into estrogen-active 8-prenylnaringenin. Possemiers and colleagues [38] invented and patented the demethylation of isoxanthohumol by Eubacterium limosum in Brain Heart Infusion (BHI) broth with a conversion of up to $50 \%$ and up to $90 \%$ by using specially selected strains [39]. Fu et al. [40] used fungi for the demethylation of isoxanthohumol with a conversion of up to $1.5 \%$. Thus, there is a big difference between the yield of conversion of bacteria and fungi. There is also a second approach by organic synthesis where pure substances are used for conversion, which is based on either the efficient synthesis of the phytoestrogen 8-prenylnaringenin from isoxanthohumol with magnesium iodide etherate [41] or the synthesis of the mixture of 8-prenylnaringenin and 6-prenylnaringenin from xanthohumol using lithium chloride ( $\mathrm{LiCl}$ ), dimethylformamide (DMF) and microwave irradiation (MW) [42]. There is also an alternative in the application of metal oxides as a catalyst in the conversion of xanthohumol to 8-prenylnaringenin [43]. However, the industrial application of this biotransformation process is associated with a number of issues. The microorganism used belongs to risk class 2 according to the German Federal Institute of Occupational Safety and Health [44], and the trials were also carried out only with pure substances. Therefore, the industrial application of this procedure for the production of medicinal preparations or food supplements with estrogenic activity is likely to be associated with additional costs that are associated with preparing pure isoxanthohumol or xanthohumol and purification of the product. Our procedure uses edible $\mathrm{MgO}$ as a catalyst for the conversion of desmethylxanthohumol to 8-prenylnaringenin directly in the spent hops after $\mathrm{CO}_{2}$ extraction. This conversion is highly suitable for hop varieties with a very high content of desmethylxanthohumol, such as the hop variety Vital of Czech origin. The resulting materials after conversion contain a high content of 8-prenylnaringenin, which can be used directly in the production of food supplements for the relief of menopausal symptoms.

From this point of view, a simple microbial-free physicochemical process that exploits hops, or even better, the residual material from the production of hop pellets or $\mathrm{CO}_{2}$ extracts, has great potential.

\subsection{Analysis of Starting Hop Material}

The starting material used in this study was pellets produced as a residue after the supercritical $\mathrm{CO}_{2}$ extraction of hops (variety Vital). This material does not yet have any industrial use. The contents of the main hop prenylflavonoids (xanthohumol, isoxanthohumol, 6-prenylnaringenin, 8-prenylnaringenin and desmethylxanthohumol) determined by HPLC-PDA and expressed as $\mathrm{mg} / 100 \mathrm{~g}$ of dry matter (DW) are summarized in Table 1. The predominant prenylflavonoid in the material was xanthohumol $(920.2 \mathrm{mg} / 100 \mathrm{gDW})$, and the content of estrogenically active 8-prenylnaringenin and its precursor desmethylxanthohumol were $17.1 \mathrm{mg} / 100 \mathrm{~g}$ and $97.4 \mathrm{mg} / 100 \mathrm{gDW}$, respectively. The 8-prenylnaringenin content was higher than in a previous study [45] in the hop variety Magnum $(4.51 \mathrm{mg} / 100 \mathrm{gDW})$, as well as in hop residues after $\mathrm{CO}_{2}$ extraction (10.8 mg/100 gDW). 
Table 1. Characterization of the starting hop material.

\begin{tabular}{cc}
\hline Prenylflavonoid & (mg/100 gDW) \\
\hline Desmethylxanthohumol & 97.4 \\
8-Prenylnaringenin & 17.1 \\
6-Prenylnaringenin & 46.7 \\
Xanthohumol & 920.2 \\
Isoxanthohumol & 29.4 \\
$\alpha$-Bitter acids & 1004 \\
$\beta$-Bitter acids & n.d \\
\hline
\end{tabular}

Moisture (\%wt.) 6.2 .

In addition, extraction with nonpolar supercritical $\mathrm{CO}_{2}$ led to the removal of most hop resins [46], particularly $\alpha$-bitter acids that could cause undesirable bitter tastes [47]. The final content of these substances in the hop residue was about $1 \% w t$., whereas the initial content in the Vital hop cones ranged from 10 to $15 \%$ wt. [48]. As a residue from the production of raw material used in the brewing industry, this material does not represent a risk with regard to toxicity even at high doses, as was confirmed for all major groups of hop components [1].

These data show that the residue after $\mathrm{CO}_{2}$ extraction of the hop variety Vital is an appropriate and economically beneficial raw material for the production of food supplements with increased estrogenic activities.

\subsection{Determination of Appropriate Conditions for the Isomerization of Prenylflavonoids}

The rate of the isomerization of prenylflavonoids and structurally related hop resins is dependent on many physicochemical parameters, in particular temperature, $\mathrm{pH}$, the amount of the catalyst and the length of time for the isomerization process [49-51]. The isomerization procedure was performed without the presence of oxygen (i.e., wrapped and vacuumed).

\subsubsection{Influence of Temperature}

The catalyst was mixed with the hop material $(0.3 \% \mathrm{wt}$.), and a series of samples were heated in the oven for 9 days at different temperatures $\left(50{ }^{\circ} \mathrm{C}, 60^{\circ} \mathrm{C}\right.$ and $\left.70{ }^{\circ} \mathrm{C}\right)$. These temperatures were chosen to avoid the isomerization of xanthohumol to isoxanthohumol and the decomposition of 8-prenylnaringenin at temperatures greater than $80^{\circ} \mathrm{C}$ [52]. The average relative changes in the content of 8-prenylnaringenin in the material are shown in Figure 2. The initial concentration of 8-prenylnaringenin was at time 0, and during the total time, the content of 8-prenylnaringenin was increased (expressed in relative \%).

For the samples exposed to a low temperature $\left(50{ }^{\circ} \mathrm{C}\right)$, an approximate $31 \%$ rel. increase in the content of 8-prenylnaringenin was observed (corresponding to a change from 17.1 to $22.4 \mathrm{mg} / 100 \mathrm{gDW}$ ). The greatest increase in 8-prenylnaringenin was observed after exposure to a temperature of $70{ }^{\circ} \mathrm{C}$. Under these conditions, the final content of 8-prenylnaringenin $(29.1 \mathrm{mg} / 100 \mathrm{gDW})$ represented a $72 \%$ increase relative to the content in the starting material. The yield of 8-prenylnaringenin in the hop material isomerized at $60{ }^{\circ} \mathrm{C}$ was slightly lower (Figure 2). Extensive degradation of 8-prenylnaringenin occurred at temperatures above $70^{\circ} \mathrm{C}$. After 4 days of isomerization at $80^{\circ} \mathrm{C}$, the level of 8-prenylnaringenin was below the limit of detection for the method.

Therefore, the isomerization of other prenylflavonoids to 8-prenylnaringenin was strongly dependent on temperature, which was similar to the reactions of other nonpolar hop components [36,49]. At low temperatures, the transformation was also low, but very high temperatures led to an undesirable decomposition of the products resulting in reduced yields of 8-prenylnaringenin and other prenylflavonoids [52]. For an industrialscale technological process, it is important to consider economic factors. Energy demands for the isomerization of the material at $70{ }^{\circ} \mathrm{C}$ would be significantly higher than at $60^{\circ} \mathrm{C}$, and it would therefore be necessary for a producer to make decisions based on an overall economic evaluation of the process. 


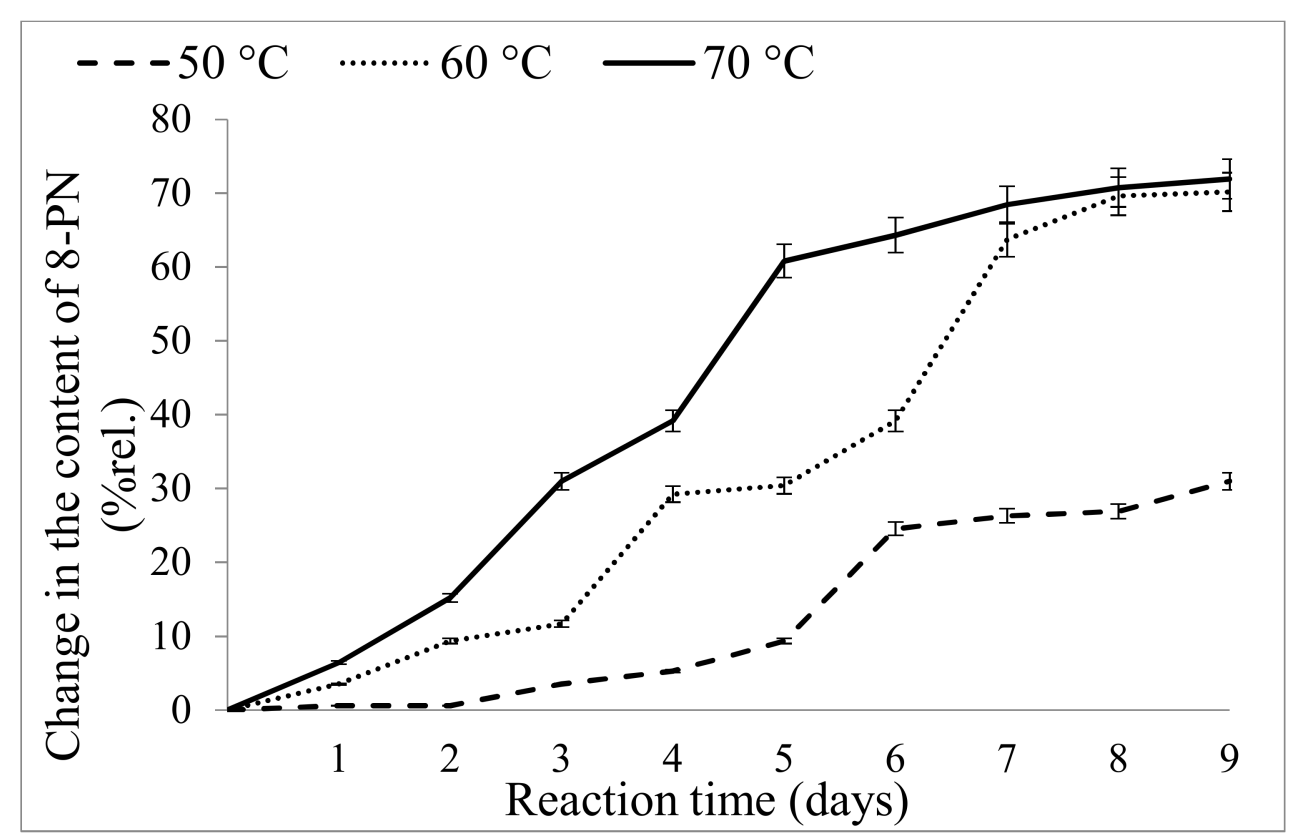

Figure 2. Isomerization of desmethylxanthohumol to 8-prenylnaringenin in the spent hops at different temperatures.

\subsubsection{Influence of Reaction Time}

The samples were mixed with the catalyst $(0.3 \% \mathrm{wt}$.) and left in the oven for 9 days at $60{ }^{\circ} \mathrm{C}$. The results (Figure 3 ) show that beginning from day 6 , there was a shift in the ratio between 6-prenylnaringenin and 8-prenylnaringenin in favor of the latter. The content of 8-prenylnaringenin increased slightly even after the complete conversion of desmethylxanthohumol, suggesting that the conversion of 6-prenylnaringenin to 8-prenylnaringenin had occurred.

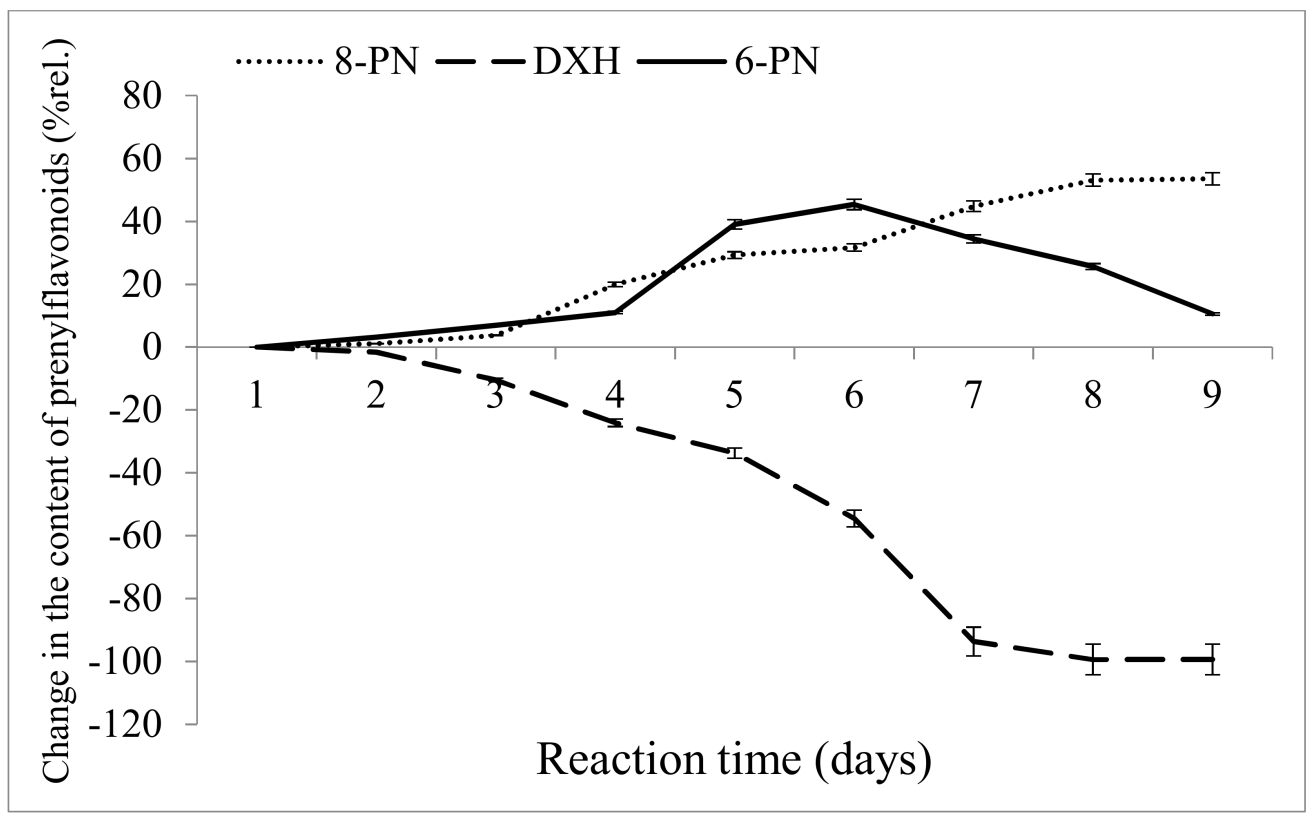

Figure 3. Isomerization of desmethylxanthohumol to 6-prenylnaringenin and 8-prenylnaringenin in the spent hops after $\mathrm{CO}_{2}$ extraction.

To verify this, a mixture of prenylnaringenin standards was exposed to model conditions (catalysis at a concentration of $0.3 \% \mathrm{wt}$., temperature of $60{ }^{\circ} \mathrm{C}$, incubation period 
2 days), and the concentrations of the two isomers in solution were determined. The analysis showed that 6-prenylnaringenin was converted to 8-prenylnaringenin (Figure 4).

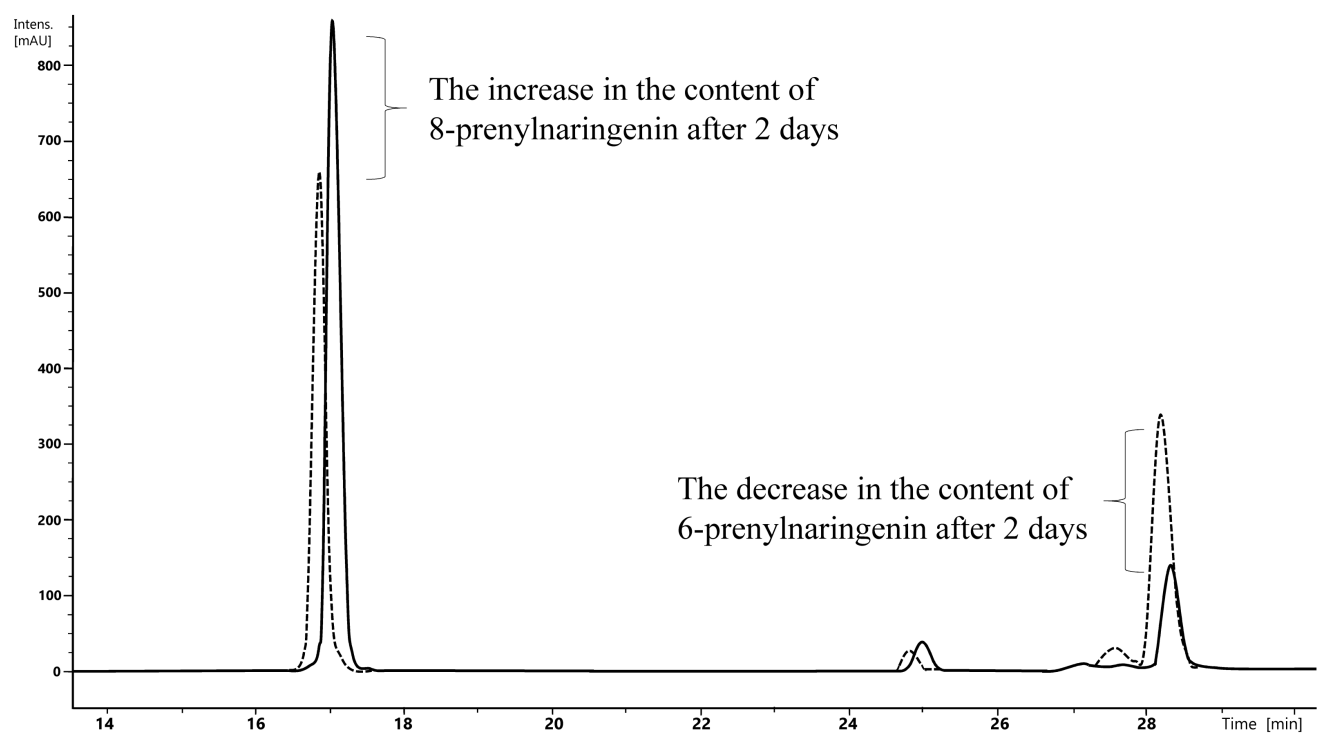

Figure 4. Chromatogram showing changes in levels of 8-prenylnaringenin and 6-prenylnaringenin, measured at $\lambda=290 \mathrm{~nm}$ in standard solutions over a 2-day period.

Based on data obtained by analyzing the changes in 8-prenylnaringenin, as illustrated in Figure 3, an 8-day reaction time was chosen as suitable for the isomerization of desmethylxanthohumol at a temperature of $60^{\circ} \mathrm{C}$. A longer isomerization time ( 9 days) would not be economically viable for manufacturers due to the higher costs, which are compensated only by a negligible increase in the content of 8-prenylnaringenin.

\subsubsection{Influence of Magnesium Ions}

According to the available literature, the isomerization of some hop compounds is $\mathrm{pH}$-dependent [53], where a higher $\mathrm{pH}$ stimulates the reaction rate. A similar reaction is commonly used for the production of iso-pellets, a brewing bittering material in which $\alpha$-bitter acids are converted into iso- $\alpha$-bitter acids by the addition of a small quantity of food grade magnesium oxide (1-3\%wt.) or hydroxide at a temperature of $50{ }^{\circ} \mathrm{C}$, which increases the $\mathrm{pH}$ and acts as a catalyst [54]. Magnesium oxide was chosen in our study to accelerate the isomerization of desmethylxanthohumol to 8-prenylnaringenin. The aim was to identify the appropriate amount of magnesium oxide that needed to be added to the hop material.

The data suggest (Figure 5) that the most appropriate amount of the catalyst was $0.3 \%$ wt. of the initial material. By day 8, the increase in 8-prenylnaringenin content was almost $70 \%$ rel.

The use of greater amounts of the catalyst was unsatisfactory in terms of the yield of 8-prenylnaringenin, where heating the mixture with $3 \% \mathrm{wt}$. of magnesium oxide led only to a $24 \%$ rel. increase in 8-prenylnaringenin over the 8-day period. Even the isomerization performed without a catalyst was significantly better in this respect ( $41.6 \%$ increase).

As is clear from Figure 6, in the case of the $3 \% w t$. catalyst the lower content of 8-prenylnaringen was due to a shift in the balance of products toward 6-prenylnaringenin. We assumed that the higher level of the catalyst significantly accelerated the conversion of desmethylxanthohumol to 6-prenylnaringenin but also inhibited the conversion of 6prenylnaringenin to 8-prenylnaringenin. The addition of the $3 \% \mathrm{wt}$. catalyst caused a $72.8 \%$ rel. increase in the content of 6-prenylnaringenin in the final product (on day 9 of isomerization) compared to samples without the addition of the catalyst (34.7\%rel.). 


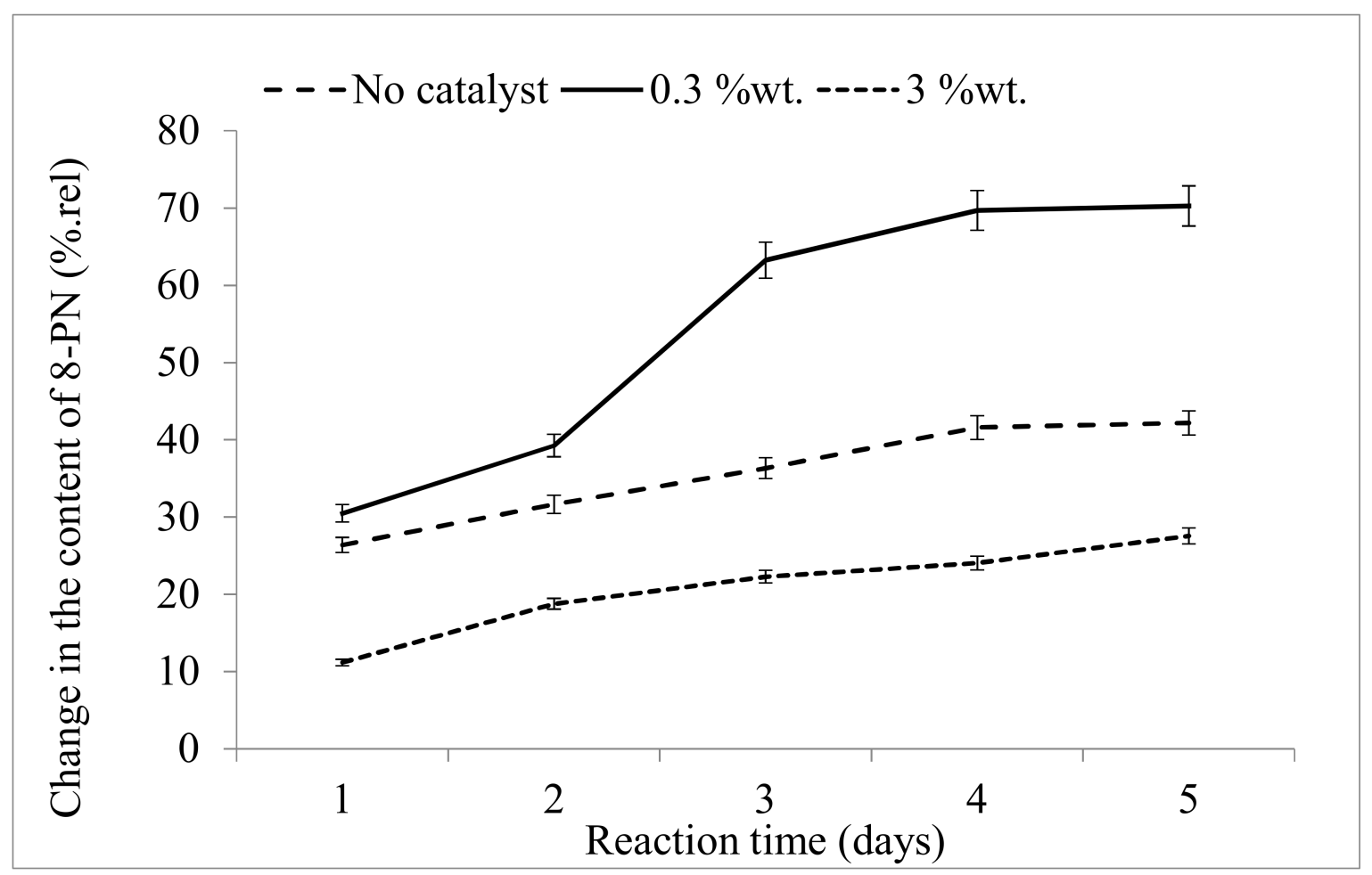

Figure 5. Catalyst-dependent changes in the content of 8-prenylnaringenin (8-PN) relative to the content in starting material.

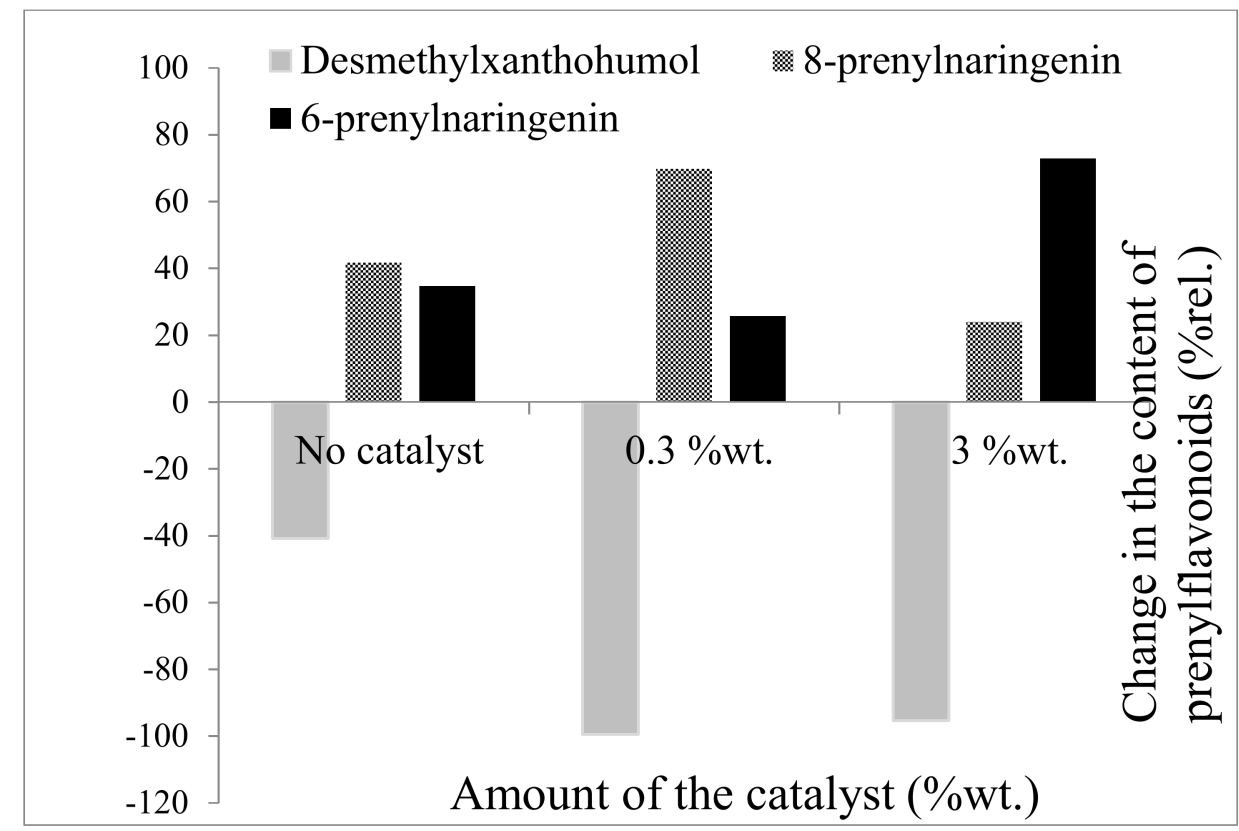

Figure 6. Catalyst-dependent changes in the content of prenylflavonoids after 9 days of isomerization relative to the content in starting material.

\section{Materials and Methods}

\subsection{Chemicals}

All the chemicals used were of HPLC gradient or analytical grade. Diethyl ether was purchased from Lach-Ner, Czech Republic. Acetonitrile was purchased from SigmaAldrich, Germany. Hydrochloric acid (38\%) and formic acid were purchased from Penta, Czech Republic. The xanthohumol standard (95\%) was purchased from Hopsteiner, Germany. Standards of isoxanthohumol, 6-prenylnaringenin and 8-prenylnaringenin were 
purchased from Toroma Organics Ltd., Germany. Milli-Q water was used for HPLC analysis. Magnesium oxide light (BP, Ph. Eur., USP, E 530) extra pure, pharma grade was purchased from Merck Life Science Ltd., Prague, Czech Republic.

\subsection{Hop Material}

Residual hop material was prepared by Flaveko Trade, Czech Republic, from the hop variety Vital using supercritical carbon dioxide extraction $\left(50^{\circ} \mathrm{C}, 290 \mathrm{bar}\right)$. The consistency of the hop residue after extraction was powdery, and this material was used for the isomerization experiments.

\subsection{Isomerisation of Prenylflavonoids in Hop Material}

From the original material, which was first homogenized on a laboratory homogenizer, about $10 \mathrm{~g}$ was weighed and then the appropriate amount (0.3-3\%wt.) of magnesium oxide catalyst was added. This mixture was thoroughly homogenized and subsequently transferred to double-sided plastic foil from which air was sucked out and sealed by means of a vacuum foil welder. The prepared material was then placed in an oven for 1-10 days at adjusted temperatures $\left(50,60\right.$ and $\left.70^{\circ} \mathrm{C}\right)$. After the completion of the isomerization reaction, the material was analyzed according to the procedure described in part 3.4.

\subsection{Preparation of Samples and HPLC-PDA Analysis}

Analyses of prenylflavonoids (xanthohumol, isoxanthohumol, 6-prenylnaringenin and 8-prenylnaringenin) in hop material were performed using a method commonly used for the determination of $\alpha$ - and $\beta$-bitter acids in hops based on the extraction with a diethyl ether-methanol mixture and the subsequent analysis by an HPLC with photodiode array detection [55]. This method was slightly modified to achieve better yields and the separation of the desired prenylflavonoids.

The hop material was homogenized in a laboratory mill, $1 \mathrm{~g}$ was weighed accurately to four decimal places and was then extracted with $20 \mathrm{~mL}$ of methanol and $100 \mathrm{~mL}$ of diethyl ether for $30 \mathrm{~min}$ on a shaker. Subsequently, $40 \mathrm{~mL}$ of $0.1 \mathrm{M}$ hydrochloric acid were added, and the extraction was continued for another $10 \mathrm{~min}$. Then, $20 \mathrm{~mL}$ of the diethyl ether phase was transferred to a $100 \mathrm{~mL}$ flask and evaporated to dryness. After evaporation, the extract was diluted with $5 \mathrm{~mL}$ of methanol, filtered through a $0.45 \mu \mathrm{m}$ PTFE filter and transferred to a vial.

HPLC analyses were performed at $25 \pm 1{ }^{\circ} \mathrm{C}$. The samples (10 $\mu \mathrm{L}$ injected volume) were analyzed using an Agilent 1100 series system (Agilent Technologies, Santa Clara, CA, USA) equipped with a photodiode array detector (PDA). Separation was achieved using an ECLIPSE XDB-C18 column ( $5 \mu \mathrm{m}, 4.6 \times 150 \mathrm{~mm}$; Agilent, Santa Clara, CA, USA). The mobile phase consisted of water with $0.05 \%$ formic acid (solvent $\mathrm{A}$ ) and acetonitrile with $0.05 \%$ formic acid (solvent $\mathrm{B}$ ). The flow rate was $0.8 \mathrm{~mL} / \mathrm{min}$, and the solvent composition varied as follows: $0-40 \mathrm{~min}, 35-62 \% \mathrm{~B} ; 40-42 \mathrm{~min}, 62-95 \% \mathrm{~B} ; 42-47 \mathrm{~min}, 95 \% \mathrm{~B}$. The HPLC-PDA analysis was performed by monitoring two different wavelengths: $290 \mathrm{~nm}$ for isoxanthohumol, 6-prenylnaringenin and 8-prenylnaringenin and $370 \mathrm{~nm}$ for xanthohumol.

\subsection{HPLC-PDA Method of Analysis Validation}

The HPLC method validation parameters (repeatability, limit of detection (LOD) and limit of quantification (LOQ)) were determined by repeating the process of isolation and analysis of prenylflavonoids (xanthohumol, isoxanthohumol, desmethylxanthohumol, 8prenylnaringenin and 6-prenylnaringenin) eight times. The repeatability of the method was expressed as the relative standard deviation (RSD). The RSD for xanthohumol, isoxanthohumol and 8-prenylnaringenin was $4.9 \%, 4.5 \%$ and $3.7 \%$, respectively. The LOD of this method for 8-prenylnaringenin was $0.713 \mathrm{mg} / 100 \mathrm{~g}$, and the LOQ was $2.375 \mathrm{mg} / 100 \mathrm{~g}$. This method can be considered reliable and is therefore suitable for the determination of prenylflavonoids in hop material. 


\subsection{Statistics}

All results were expressed as the average values of three experiments that were repeated independently.

\section{Conclusions}

The aim of this study was to define suitable conditions for the optimal conversion of estrogenically inactive desmethylxanthohumol to the effective phytoestrogen, 8-prenylnaringenin. The starting material for the experiments was the residual material of the hop variety Vital after extraction with supercritical carbon dioxide, and the isomerization reaction took place in solid state.

The effects of temperature, the length of the process and the amount of the catalyst were studied, and the appropriate conditions were identified as:

- Isomerization for 8 days;

- A temperature of $60^{\circ} \mathrm{C}$;

- The use of a $0.3 \%$ wt. magnesium oxide catalyst.

By applying these parameters, a product containing $29 \mathrm{mg}$ of 8-prenylnaringenin per $100 \mathrm{gDW}$ of hop material was prepared. This represented a more than $70 \%$ increase relative to the content of 8-prenylnaringenin in the starting material. Unlike the previously published procedures, this simple method does not involve the risks associated with the use of a potentially pathogenic micro-organism. The production costs should also be significantly lower, as costs associated with the preparation of the culture medium and isolation of the finished product are eliminated. The prepared material can be used directly as a component of functional foods or dietary supplements, developed specifically to help alleviate menopausal problems [56]. Where this material may be used for the production of dietary supplements, a 0.8 g capsule would contain $232 \mu \mathrm{g}$ of 8-prenylnaringenin, which is comparable to commercially available products used to alleviate menopausal discomfort. In addition, other prenylflavonoids with proven health-promoting properties (i.e., xanthohumol and isoxanthohumol) are preserved in the material, thus representing an additional benefit that is associated with the use of products made from this material.

This procedure was used in the production of the food supplement MenoPrima Bella ${ }^{\circledR}$ for the company Biomedica (https: / / www.bio-medica.cz/, accessed on 6 October 2021).

Author Contributions: Conceptualization, P.D. and M.K.; methodology, validation and analyses, T.H., L.J. and K.F.; writing—original draft preparation, T.H.; writing—review and editing, M.K.P.D. and L.J.; supervision, P.D.; project administration, P.D.; funding acquisition, P.D. All authors have read and agreed to the published version of the manuscript.

Funding: This research was funded by the Technology Agency of the Czech Republic, grant number TE02000177. The reduced APC was funded by the Faculty of Food and Biochemical Technology, University of Chemistry and Technology, Prague.

Conflicts of Interest: The authors declare no conflict of interest. The funders had no role in the design of the study; in the collection, analyses, or interpretation of data; in the writing of the manuscript or in the decision to publish the results.

\section{References}

1. Karabín, M.; Hudcová, T.; Jelínek, L.; Dostálek, P. Biologically Active Compounds from Hops and Prospects for Their Use. Compr. Rev. Food Sci. Food Saf. 2016, 15, 542-567. [CrossRef] [PubMed]

2. Zanoli, P.; Zavatti, M. Pharmacognostic and pharmacological profile of Humulus lupulus L. J. Ethnopharmacol. 2008, 116, 383-396. [CrossRef]

3. Almaguer, C.; Schonberger, C.; Gastl, M.; Arendt, E.K.; Becker, T. Humulus lupulus-A story that begs to be told. A review. J. Inst. Brew. 2014, 120, 289-314. [CrossRef]

4. Krofta, K.; Vrabcova, S.; Mravcova, L.; Dostalek, P.; Karabin, M.; Jelinek, L.; Hudcova, T. Classification of Czech Hops According to their Contents of Prenylflavonoids. Kvasny Prum. 2015, 61, 62-68. [CrossRef] 
5. Hartkorn, A.; Hoffmann, F.; Ajamieh, H.; Vogel, S.; Heilmann, J.; Gerbes, A.L.; Vollmar, A.M.; Zahler, S. Antioxidant Effects of Xanthohumol and Functional Impact on Hepatic Ischemia-Reperfusion Injury. J. Nat. Prod. 2009, 72, 1741-1747. [CrossRef] [PubMed]

6. Miranda, C.L.; Stevens, J.F.; Ivanov, V.; McCall, M.; Frei, B.; Deinzer, M.L.; Buhler, D.R. Antioxidant and prooxidant actions of prenylated and nonprenylated chalcones and flavanones in vitro. J. Agric. Food Chem. 2000, 48, 3876-3884. [CrossRef] [PubMed]

7. Ambroz, M.; Lnenickova, K.; Matouskova, P.; Skalova, L.; Bousova, I. Antiproliferative Effects of Hop-derived Prenylflavonoids and Their Influence on the Efficacy of Oxaliplatine, 5-fluorouracil and Irinotecan in Human ColorectalC Cells. Nutrients 2019, 11, 879. [CrossRef]

8. Hudcova, T.; Bryndova, J.; Fialova, K.; Fiala, J.; Karabin, M.; Jelinek, L.; Dostalek, P. Antiproliferative effects of prenylflavonoids from hops on human colon cancer cell lines. J. Inst. Brew. 2014, 120, 225-230. [CrossRef]

9. Gerhauser, C.; Alt, A.; Heiss, E.; Gamal-Eldeen, A.; Klimo, K.; Knauft, J.; Neumann, I.; Scherf, H.R.; Frank, N.; Bartsch, H.; et al. Cancer chemopreventive activity of Xanthohumol, a natural product derived from hop. Mol. Cancer Ther. 2002, 1, 959-969.

10. Araujo, J.R.; Goncalves, P.; Martel, F. Chemopreventive effect of dietary polyphenols in colorectal cancer cell lines. Nutr. Res. 2011, 31, 77-87. [CrossRef]

11. Gerhauser, C. Broad spectrum antiinfective potential of xanthohumol from hop (Humulus lupulus L.) in comparison with activities of other hop constituents and xanthohumol metabolites. Mol. Nutr. Food Res. 2005, 49, 827-831. [CrossRef]

12. Stompor, M.; Zarowska, B. Antimicrobial Activity of Xanthohumol and Its Selected Structural Analogues. Molecules 2016, 21, 608. [CrossRef]

13. Peluso, M.R.; Miranda, C.L.; Hobbs, D.J.; Proteau, R.R.; Stevens, J.F. Xanthohumol and Related Prenylated Flavonoids Inhibit Inflammatory Cytokine Production in LPS-Activated THP-1 Monocytes: Structure-Activity Relationships and In Silico Binding to Myeloid Differentiation Protein-2 (MD-2). Planta Med. 2010, 76, 1536-1543. [CrossRef]

14. Monteiro, R.; Calhau, C.; Silva, A.O.E.; Pinheiro-Silva, S.; Cuerreiro, S.; Gartner, F.; Azevedo, I.; Soares, R. Xanthohumol inhibits inflammatory factor production and angiogenesis in breast cancer xenografts. J. Cell. Biochem. 2008, 104, 1699-1707. [CrossRef] [PubMed]

15. Stulikova, K.; Karabin, M.; Nespor, J.; Dostalek, P. Therapeutic Perspectives of 8-Prenylnaringenin, a Potent Phytoestrogen from Hops. Molecules 2018, 23, 660. [CrossRef]

16. Milligan, S.R.; Kalita, J.C.; Heyerick, A.; Rong, H.; De Cooman, L.; De Keukeleire, D. Identification of a potent phytoestrogen in hops (Humulus lupulus L.) and beer. J. Clin. Endocrinol. Metab. 1999, 84, 2249-2252. [CrossRef] [PubMed]

17. Chadwick, L.R.; Pauli, G.F.; Farnsworth, N.R. The pharmacognosy of Humulus lupulus L. (hops) with an emphasis on estrogenic properties. Phytomedicine 2006, 13, 119-131. [CrossRef]

18. Koch, W.; Heim, G. Hormone in Hopfen und Bier. Brauwissenschaft 1953, 8, 152-153.

19. Schaefer, O.; Humpel, M.; Fritzemeier, K.H.; Bohlmann, R.; Schleuning, W.D. 8-Prenyl naringenin is a potent ER alpha selective phytoestrogen present in hops and beer. J. Steroid Biochem. Mol. Biol. 2003, 84, 359-360. [CrossRef]

20. Helle, J.; Kraker, K.; Bader, M.I.; Keiler, A.M.; Zierau, O.; Vollmer, G.; Welsh, J.; Kretzschmar, G. Assessment of the proliferative capacity of the flavanones 8-prenylnaringenin, 6-(1.1-dimethylallyl)naringenin and naringenin in MCF-7 cells and the rat mammary gland. Mol. Cell. Endocrinol. 2014, 392, 125-135. [CrossRef]

21. Effenberger, K.E.; Westendorf, J. Hop-Derived Phytoestrogens Alter Osteoblastic Phenotype and Gene Expression. In Beer in Health and Disease Prevention; Preedy, V.R., Ed.; Elsevier Inc.: San Diego, CA, USA, 2009; pp. 735-745.

22. van Duursen, M.B.M.; Smeets, E.E.J.W.; Rijk, J.C.W.; Nijmeijer, S.M.; van den Berg, M. Phytoestrogens in menopausal supplements induce ER-dependent cell proliferation and overcome breast cancer treatment in an in vitro breast cancer model. Toxicol. Appl. Pharmacol. 2013, 269, 132-140. [CrossRef]

23. Monteiro, R.; Faria, A.; Azevedo, I.; Calhau, C. Modulation of breast cancer cell survival by aromatase inhibiting hop (Humulus lupulus L.) flavonoids. J. Steroid Biochem. Mol. Biol. 2007, 105, 124-130. [CrossRef] [PubMed]

24. Cos, P.; De Bruyne, T.; Apers, S.; Vanden Berghe, D.; Pieters, L.; Vlietinck, A.J. Phytoestrogens: Recent developments. Planta Med. 2003, 69, 589-599. [PubMed]

25. Takahashi, T.A.; Johnson, K.M. Menopause. Med. Clin. N. Am. 2015, 99, 521-534. [CrossRef] [PubMed]

26. Stuenkel, C.A.; Davis, S.R.; Gompel, A.; Lumsden, M.A.; Murad, M.H.; Pinkerton, J.V.; Santen, R.J. Treatment of Symptoms of the Menopause: An Endocrine Society Clinical Practice Guideline. J. Clin. Endocrinol. Metab. 2015, 100, 3975-4011. [CrossRef] [PubMed]

27. Lobo, R.A. Hormone-replacement therapy: Current thinking. Nat. Rev. Endocrinol. 2017, 13, 220-231. [CrossRef]

28. Ming, L.G.; Lv, X.; Ma, X.N.; Ge, B.F.; Zhen, P.; Song, P.; Zhou, J.; Ma, H.P.; Xian, C.J.; Chen, K.M. The Prenyl Group Contributes to Activities of Phytoestrogen 8-Prenynaringenin in Enhancing Bone Formation and Inhibiting Bone Resorption In Vitro. Endocrinology 2013, 154, 1202-1214. [CrossRef]

29. Tobe, H.; Muraki, Y.; Kitamura, K.; Komiyama, O.; Sato, Y.; Sugioka, T.; Maruyama, H.B.; Matsuda, E.; Nagai, M. Bone resorption inhibitors from hop extract. Biosci. Biotechnol. Biochem. 1997, 61, 158-159. [CrossRef]

30. Humpel, M.; Isaksson, P.; Schaefer, O.; Kaufmann, U.; Ciana, P.; Maggi, A.; Schleuning, W.D. Tissue specificity of 8prenylnaringenin: Protection from ovariectomy induced bone loss with minimal trophic effects on the uterus. J. Steroid Biochem. Mol. Biol. 2005, 97, 299-305. [CrossRef] 
31. Vázquez Loureiro, P.; Hernández Jiménez, I.; Sendón, R.; Rodriguez-Bernaldo de Quirós, A.; Barbosa-Pereira, L. Determination of Xanthohumol in Hops, Food Supplements and Beers by HPLC. Foods 2019, 8, 435. [CrossRef]

32. Heyerick, A.; Vervarcke, S.; Depypere, H.; Bracke, M.; De Keukeleire, D. A first prospective, randomized, double-blind, placebocontrolled study on the use of a standardized hop extract to alleviate menopausal discomforts. Maturitas 2006, 54, 164-175. [CrossRef] [PubMed]

33. Milligan, S.R. Reproductive and Estrogenic Effects of 8-Prenylnaringenin in Hops. In Beer in Health and Disease Prevention; Preedy, V.R., Ed.; Elsevier Inc.: San Diego, CA, USA, 2009; pp. 711-723.

34. Milligan, S.R.; Kalita, J.C.; Pocock, V.; Van de Kauter, V.; Stevens, J.F.; Deinzer, M.L.; Rong, H.; De Keukeleire, D. The endocrine activities of 8-prenylnaringenin and related hop (Humulus lupulus L.) flavonoids. J. Clin. Endocrinol. Metab. 2000, 85, $4912-4915$. [CrossRef] [PubMed]

35. Diller, R.A.; Riepl, H.M.; Rose, O.; Frias, C.; Henze, G.; Prokop, A. Desmethylxanthohumol from Hops, Chemistry and Biological Effects. In Beer in Health and Disease Prevention; Preedy, V.R., Ed.; Elsevier Inc.: San Diego, CA, USA, 2009; pp. 703-709.

36. Stevens, J.F.; Taylor, A.W.; Clawson, J.E.; Deinzer, M.L. Fate of xanthohumol and related prenylflavonoids from hops to beer. J. Agric. Food Chem. 1999, 47, 2421-2428. [CrossRef]

37. Nesvadba, V.; Krofta, K.; Polončíková, Z. Hop (Humulus lupulus L.) breeding aimed at high contents of desmethylxanthohumol (DMX). Agriculture (Pol'nohospodárstvo) 2011, 57, 105-109. [CrossRef]

38. Possemiers, S.; Verstraete, W.; Heyerick, A.; De Keukeleire, D. Enzymatic Demethylation of Flavonoids. WO2006099699A1, 28 September 2006.

39. Possemiers, S.; Heyerick, A.; Robbens, V.; De Keukeleire, D.; Verstraete, W. Activation of proestrogens from hops (Humulus lupulus L.) by intestinal microbiota; Conversion of isoxanthohumol into 8-prenylnaringenin. J. Agric. Food Chem. 2005, 53, 6281-6288. [CrossRef]

40. Fu, M.L.; Wang, W.; Chen, F.; Dong, Y.C.; Liu, X.J.; Ni, H.; Chen, Q.H. Production of 8-prenylnaringenin from isoxanthohumol through biotransformation by fungi cells. J. Agric. Food Chem. 2011, 59, 7419-7426. [CrossRef]

41. Aniol, M.; Szymanska, K.; Zolnierczyk, A. An effcient synthesis of the phytoestrogen 8-prenylnaringenin from isoxanthohumol with magnesium iodide etherate. Tetrahedron 2008, 64, 9544-9547. [CrossRef]

42. Urmann, C.; Riepl, H. Semi-Synthetic Approach Leading to 8-Prenylnaringenin and 6-Prenylnaringenin: Optimization of the Microwave-Assisted Demethylation of Xanthohumol Using Design of Experiments. Molecules 2020, 25, 4007. [CrossRef]

43. Wilhelm, H.; Wessjohann, L.A. An efficient synthesis of the phytoestrogen 8-prenylnaringenin from xanthohumol by a novel demethylation process. Tetrahedron 2006, 62, 6961-6966. [CrossRef]

44. Federal Institute of Occupational Safety and Health. Classification of Prokaryotes (Bacteria and Archaea) into Risk Groups. Available online: https:/ / www.baua.de/EN/Service/Legislative-texts-and-technical-rules/Rules/TRBA/pdf/TRBA-466.pdf? _ blob=publicationFile\&v=2 (accessed on 26 November 2020).

45. Rong, H.; Zhao, Y.; Lazou, K.; De Keukeleire, D.; Milligan, S.R.; Sandra, P. Quantitation of 8-prenylnaringenin, a novel phytoestrogen in hops (Humulus lupulus L.), hop products, and beers, by benchtop HPLC-MS using electrospray ionization. Chromatographia 2000, 51, 545-552. [CrossRef]

46. Jelinek, L.; Karabin, M.; Kotlikova, B.; Hudcova, T.; Dostalek, P. Application of a hop by-product in brewing: Reduction in the level of haze-active prolamines and improved antioxidant properties of the beer. J. Inst. Brew. 2014, 120, 99-104. [CrossRef]

47. Intelmann, D.; Batram, C.; Kuhn, C.; Haseleu, G.; Meyerhof, W.; Hofmann, T. Three TAS2R Bitter Taste Receptors Mediate the Psychophysical Responses to Bitter Compounds of Hops (Humulus lupulus L.) and Beer. Chemosens. Percept. 2009, 2, 118-132. [CrossRef]

48. Krofta, K.; Patzak, J.; Nesvadba, V.; Mikyska, A.; Slaby, M.; Cejka, P. VITAL-The Czech hop hybrid variety-Part I. Kvasny Prum. 2013, 59, 2-13. [CrossRef]

49. Kostrzewa, D.; Dobrzynska-Inger, A.; Roj, E.; Grzeda, K.; Kozlowski, K. Isomerization of hop extract alpha-acids. J. Inst. Brew. 2016, 122, 493-499. [CrossRef]

50. Maes, F.; De Keukeleire, D.; Heyerick, A. Production of Hop Extracts Having Oestrogenic and Antiproliferative Bioactivity. US20110130447A1, 2 June 2011.

51. Magalhaes, P.J.; Carvalho, D.O.; Cruz, J.M.; Guido, L.F.; Barros, A.A. Fundamentals and Health Benefits of Xanthohumol, a Natural Product Derived from Hops and Beer. Nat. Prod. Commun. 2009, 4, 591-610. [CrossRef]

52. Karabin, M.; Jelinek, L.; Kincl, T.; Hudcova, T.; Kotlikova, B.; Dostalek, P. New approach to the production of xanthohumolenriched beers. J. Inst. Brew. 2013, 119, 98-102. [CrossRef]

53. Jaskula, B.; Kafarski, P.; Aerts, G.; De Cooman, L. A kinetic study on the isomerization of hop alpha-acids. J. Agric. Food Chem. 2008, 56, 6408-6415. [CrossRef]

54. Burkhardt, R.J.; Wilson, R.J. Process for the Preparation of Isomerized Hop Pellets. US4946691A, 7 August 1990.

55. American Society of Brewing Chemists. ASBC Methods of Analysis, Hops 14. $\alpha$-Acids and $\beta$-Acids in Hops and Hop Extracts by HPLC (International Method). Available online: http:/ / methods.asbcnet.org/methods/hops-14.pdf (accessed on 26 November 2020).

56. Dostalek, P.; Hudcova, T.; Jelinek, L.; Fialova, K.; Karabin, M. Method for Preparing Hop Material with Increased Content 8-Prenylnaringenin. CZ 307451 B6 20180905, 5 September 2018. 